\title{
Agent Affecting Digestive System or Metabolism
}

National Cancer Institute

\section{Source}

National Cancer Institute. Agent Affecting Digestive System or Metabolism. NCI

Thesaurus. Code C78276.

An agent that exerts an effect on metabolism or any anatomic entity that is part of the gastrointestinal tract. 